\title{
CREATIVE CHARACTER OF RELIGION IN MAINTAINING NATIONAL IDENTITY AMONG MEMBERS OF BELARUSIAN ETHIC MINORITY IN POLAND IN DEMOCRATIC CONDITIONS
}

\author{
Andrzej SADOWSKI \\ University of Białystok, \\ Institute of Sociology, \\ Department of Sociology of Multiculturalism \\ Plac Uniwersytecki 1, 15-420 Białystok, Poland \\ E-mail: a.sadowski@uwb.edu.pl
}

Received 6 July 2016; accepted 7 October 2016

\begin{abstract}
The primary objective of this article is to shift a few hypotheses on the relationship between religion and nation. In the beginning of the article I present the interrelations between a religion and a nation being analyzed in the literature while trying to answer the question why nations need religion. Next, I present the role and importance of Orthodox Church in Poland, being the criterion of ethnicity affiliation for Belarusian national minority in Poland, particularly in the Podlaskie Voivodeship as the main area of residence for this community. In the nearest perspective, the Orthodox religion is likely to play a significant part in the process of forming Polish multi-ethnic and multinational creative society.

Keywords: Belarusian national minority, creativity, Orthodox denomination and its national identity.
\end{abstract}

\section{Introduction}

The main aim of the article is to answer the question what significance Orthodox religion holds considering both forming and maintaining national identity within Belarusian national minority in Poland in democratic conditions. The title of the article implies that there are at least three keywords to be considered: religion (here understood as an Orthodox denomination), Belarusian national minority and its national identity. Presenting the significance of religion while maintaining national identity really means analyzing the functions of Orthodox religion towards the national condition of Belarusian minority in Poland. Moreover, it needs to be discussed if these functions are more or rather less powerful within the civil society.

The article was based on relatively rich literature considering the subject being discussed, my own studies analyzing national identity of Belarusian minority in Poland as well as on the results of the research being the part of my doctoral and M.A. seminars. 
I will make an attempt to justify the hypothesis of the Orthodox denomination in the Podlaskie Voivodeship having changed its social functions during a post-war period, from the ones holding local and civilizational traits to these being multi-ethnic and multicultural. The structure of my article is as following: firstly, I present the interrelations between a religion and a nation being analyzed in the literature while trying to answer the question why nations need religion. Next, I present the role and importance of Orthodox Church in Poland, being the criterion of ethnicity affiliation for Belarusian national minority in Poland, particularly in the Podlaskie Voivodeship as the main area of residence for this community. In my opinion, in order to understand the minority related to Orthodox Church in Poland and its complex relations to ethnicity, it is necessary to analyze the affiliation to an Orthodox community as an ethnic group and the affiliation to a religious community of the Orthodox Church followers.

The Orthodox Church forms religious, historical and cultural bases to shape several specific kinds of national identity in the Podlaskie Voivodeship. It is still conducive to residents' local and regional activity, stimulating their civil activity. In the nearest perspective, the Orthodox religion is likely to play a significant part in the process of forming Polish multi-ethnic and multinational society.

Studies analyzing the relations between religion and a nation are the ones of a complex nature (see Babiński 2004: 264). I do not include ontological analyses, concerning both religion and a nation in the paper. I assume that both religion and a nation analyzed in a sociological perspective are mainly cultural phenomena; that is why their connective analysis is optimal while adopting a cultural perspective. At the same time, it is necessary to describe that Polish borderland represents a concentration and crossing in rather small territory of several ethnic, cultural and religious borders, the territory of permanent simultaneous involvement in neighbours' cultures, knowledge of several neighbours' languages, openness to cultural diversity, perception of otherness as a norm of daily life, higher than in another territory level of tolerance. Creativity is general character of the people, who was born, stayed and died in this territory.

\section{Religion and nation in the theoretical perspective ${ }^{1}$}

My inspiration to present the relations between religion and a nation (ethnicity) were Zygmunt Bauman's reflections regarding the relations between the nation and the state. He raised a question: Why does a nation need a state and why does the state need a nation (1996: 166-183)? I will present my stance by analogy to Bauman's methodological standpoint, by asking a question: Why does nation need a religion?

\footnotetext{
${ }^{1}$ This paragraph was prepared with a reference to my article "Wyznanie prawosławne a naród - ze szczególnym uwzględnieniem województwa podlaskiego” (Sadowski 2012).
} 


\section{Nation and religion as social phenomena from the realm of culture in the conditions of a national state}

In order to analyze the relations between nation and religion, one needs to accept an initial assumption that it is the most beneficial to analyze these relations within a national state, which is a nation organized into a state and, basically, around one religion. $^{2}$

From a sociological perspective, numerous similarities between nation and religion can be indicated. Both nation and religion are social phenomena originating from the realm of culture. Complex processes of shaping the nations took place in the context of the values referring to religion. According to Grzegorz Babiński, nation and religion belong to a category of community, religious and national values belong to a sacred realm, "national symbols often become consecrated (identification with religious symbols)", "consecrating the ethnicity and ethnicizing the religion" (1999: 201-203, 2003: 16). Both religious and national ties are formed during a long historic perspective; they are referred to as primordial ties. In the process of forming patriotic attitudes, related to the ties with the nation, national elites often refer to the nation and the motherland as the sacrum phenomena, not being the subject to any debate, simply being accepted. Both nation and religion usually refer to a rich and complex sphere of emotions. Numerous nations believe to be protected by their spiritual guardians. ${ }^{3}$ Thus, it could be argued that religion and a nation are tightly interrelated and, in fact, inseparable. They mutually perform the essential social functions, being necessary to each other.

Following the methodological path marked by Bauman, the following question might be formulated: Why does a nation need religion? Responding to the question formulated in this manner will indicate the instrumental functions of religion towards the nation. First of all, religion is one of the most important nation-building factors and one of the criteria of national affiliation. The idea of chosen nation seems to contribute to nation-building processes; in this case, national distinction and religious distinction complement each other (see Bystron 1995). In my opinion, the following functions of religion are to be considered during nation-building processes, in the course of constructing national identity (see Sadowski 1991: 23-31):

- religion as the only criterion of national affiliation, overlapping religions and national/ethnic identities (ethno-religious groups, for example, Muslims in Europe, Tibetans);

- religion as a basic (one of basic) criterion of national affiliation (Northern Ireland);

\footnotetext{
${ }^{2}$ This does not frequently happen in practice, as, basically, each form of a nation state includes ethnic minorities and other religions (denominations), not being either dominant or co-dominant in nationally dominating population.

${ }^{3}$ An example is Saint Patrick treated as a founder of an Irish nation; in Poland Marian cult could serve as an example.
} 
- relatively neutral position of religion considering national affiliation (Latin America);

- religion as a factor restricting national affiliation (many people living in Muslim countries feel considerable dilemmas concerning national and religious affiliation).

Religion is an important factor during national integration based on religious and national principles. Religion provides the nation with shared values. Values related to religion often become national ones in social perception; national myths and ideas are often based on religion and its notions (the Polish people being Roman Catholics, the Russians - Orthodox Christians, the Germans - Protestants, etc.). It is worth emphasizing that religion and religious symbols are essential instruments while constructing and strengthening interethnic and international solidarity.

Powerful position of religion in the nation is conducive to reducing social inequalities existing in people's minds. Religion helps to maintain a positive myth (idea) of a nation. Important ceremonies related to the nation often carry a religious character. An important manifestation of national and religious ideas being united are nationalist movements using religious ideas, attitudes and beliefs in order to justify the superior nation's position towards the state. Religion is an important barrier in assimilation processes. Moreover, a nation and religion become united in the hardest and most difficult moments of national life when mobilizing the nation is necessary. This mobilization is possible particularly when religion and its values are employed.

In a short recapitulation of the main relations between a nation and religion two extreme ones could be indicated. These are two kinds of totalitarianism, religious and national (atheistic) ones. General analyses having been conducted so far prove that religion and a nation are a historically shaped and interrelated socio-cultural entity.

\section{Nation and religion in a pluralist society}

How are the new forms of the relations between a nation and a religion supposed to be presented in a pluralist society? Above all, it needs to be stressed that both national and religious functions of the state are fundamentally changing; the state should, or even has to, consider the fact the society is under constant change. I reckon there is a historic continuum as far as the relations between the state and religion are concerned. Its starting point is a privileged position of one religion and violence towards the followers of other religions, through the idea of tolerance (restraining the violence and the prejudice), through respecting other religions or denominations, freedom of religions and, finally, treating all religions equally. There are similar relations being observed between the state and the nation. At first, these relations are based on a dominant position of one nation and concurrent violence towards other nations and ethnic groups, through the stage of tolerance (restraining the violence and the prejudice), through the next stage of respecting other nations and ethnic groups, freedom of national affiliation granted to other nations and ethnic groups, to, finally, treating all nations and ethnic groups within a state equally. 
Pluralist society becomes civil society, where the state is all citizens' property, where all citizens are equal to law regardless their religion, national and class affiliation, having a comparable influence on the state and being able to take active part in public life. Obviously, in a civil society there are still religious, national and state matters being maintained or even developed. Is it a new kind of dominance, this time civil society's dominance over national and religion-based one?

Civil society is the first society that is a legally ordered organization of all people living in the state. This society does not try to subordinate all the communities living within the state but, on the contrary, following the will of its citizens, it tries to create the most advantageous conditions to religion-based, national, class and, certainly, civil society.

Trying to answer to the question how both religious and national communities should be treated on an equal base within the state is a huge challenge that is particularly important in a pluralist state and society based on democracy.

\section{Orthodox denomination as a criterion of national affiliation for Belarusian minority in Poland}

\section{Orthodox denomination the major criterion the affiliation to Belarusian ethnic minority}

After World War II the Orthodox denomination became the major criterion to define the affiliation to Belarusian ethnic minority in Białystok Voivodeship. It was a sparse community, when compared to its pre-war number, of Orthodox Church followers, including no more than 150 thousand people. Basically, Belarusian affiliation, as it was enacted by the authorities, corresponded with the affiliation to the community of the Orthodox Church followers in Białystok Voivodeship. These were mainly local rural communities residing in the Eastern and South Eastern part of Białystok Voivodeship. In the literature on the subject they were referred to as Orthodox community, Eastern Slavic ethnic group, local community, Belarusian community, ruski community, etc.

There were no studies performed in a post-war period related to the national awareness of an Orthodox community in Białystok region, that is why this community was described using various names and phrases. The residents themselves did not tend to demonstrate their national affiliation, they often were not able to do it. The reason why they did not demonstrate it was the fact they remembered ethnic cleansing actions during the war and just after the war, when demonstrating their national affiliation could result in deportations to the Eastern part of Europe. Moreover, they were not capable of defining their national affiliation, as they had not had their national identity formed.

Beside local, Orthodox or Belarusian identities being maintained in rural and small-town areas, Polish national identity started to appear more and more frequently. These were particularly migrants to cities, especially Białystok, expressing the conviction "I am Polish as I live in Poland". 
I believe there were at least several reasons why the identity among Orthodox Polish citizens was in the first place expressed in cities. In the cities of the Polish People's Republic it was not advantageous for people to admit they were Orthodox or Belarusian as it might have been (truly or not) related to intolerance or discrimination from Polish majority. Polish national identity was manifested in high schools and companies, factories and organizations. Major principle for Orthodox followers in Polish/ Catholic environment was to fit the environment around them, not to be different. Basically, being Belarusian as ethno-national category was maintained in rural communities concurrently with the sense of religious affiliation. Belarusian identity became more developed when teaching Belarusian language at schools was introduced. The conviction that every person residing in Poland belongs to a certain nationality, defining Orthodox citizens as the ones not being really Polish, gradual formation of Belarusian elite in Poland, education in Belarusian - all these factors contributed to transforming the Orthodox ethnic group in Białystok region into the Belarusian ethnic group, gradually becoming Belarusian ethnic minority with its complex inner structure. The Orthodox Church affiliation became the basis of being a Belarusian as well as Belarusian cultural heritage popularized in media and, gradually, Belarusian national ideology. People of Orthodox denomination living in Białystok Voivodeship until the birth of Solidarity movement were commonly and informally referred to as Belarusians, although this type of identity was not fully particularized.

From a temporal perspective, I would focus on the fact that post-war rural migrants to towns, particularly Orthodox Church followers, became city dwellers without their own identity. They were not members of local communities any more, still not being the indigenous residents of the city. Numerous Orthodox migrants to cities, being deprived of conditions letting them manifest their identity, were manipulated and marginalized, not taking active part in a public life of a city they were residents of. Their religious and social identity was regained in Orthodox communities in towns, where they still preferred to be invisible or acted as "Orthodox atheists".

\section{Modern national identity of Belarusian minority - urban conditions}

I would like to emphasize the particular significance of Orthodox denomination in the process of forming contemporary social identity among Orthodox migrants from villages to cities. This identity does not combine modernization processes being desired (in the initial stage occurring mainly in cities) with the need to reject religion - as it had been stressed in Marxist ideology; rather it gives religion its role in a modern human identity.

Since the beginning of the 1980s, a new aspect concerning the formation of national identity among Orthodox Church followers has appeared. They perceived the radical social transformation in Poland as an increasing wave of freedom movements as well as Roman Catholic Church increasing in power in Polish society. This was a reason why Orthodox Church followers became more radical, too. More and more young Orthodox followers established closer relations with the Orthodox Church, particularly it was noticeable among young city residents. It was the Solidarity movement 
that allowed people to be religious, including Orthodox followers, making it a desirable feature. At the beginning of the 1980s, there were only several Orthodox parishes in Białystok, now there are 11 parishes. As far as a national identity is concerned, it was the reason that made a category of Orthodox Belarusian community in the city more powerful. In practice, modern national identity of Belarusian minority was constructed in urban conditions.

In the situation when Belarusian is not a language of a common communication, when a secular culture does not strongly affect citizens, when history of a nation, or at least historic tradition, cannot be formally taught and received - all these factors made Orthodox Church be the basic source of the variety of shared values among Belarusians, such as their "own" religion, a sense of equality (in relation to God, but also relating to Roman Catholics), a religious dimension of the nation, commitment to land, family and ethnic group, etc. I would put a particular emphasis on the commitment to their land, the land of their ancestors, to the private motherland (territorial identity), to contemporary local communities (regional/local identity) - commitment to Polishness as a territorial and political whole. Moreover, Orthodox religion provided its followers with a variety of myths, traditions and legends, which contributes to rich cultural resources of every nation. Generally, Orthodox religion in towns reduced the sense of discomfort, deprivation and alienation that resulted in a conviction of being rejected or marginalized by the Polish majority. The importance of national movements during formation of Polish democracy combined with an increasing religious openness contributed to forming a new concept of, so called, the "new" Belarusians educated and highly qualified elite capable of promulgating and promoting Belarusian values in Poland.

I am convinced it is not the language only (see Radzik 2003: 137) ${ }^{4}$, it is neither territorial identity nor Belarusian memory or contacts with Belarus, these are rather religious rituals and beliefs in towns and, consequently, in villages that are the factors contributing to the increase of Belarusian national identity. The Orthodox religion in the Podlaskie Voivodeship contributes to restraining assimilation processes towards being Polish.

The analysis of a condition of national identity I have done indicate that, basically, the respondents (over 60\% Orthodox followers) define themselves as the Orthodox Polish. The analysis I have performed approximately indicates that about one-third Orthodox residents refer to themselves as being Belarusians. The rest part $(10-5 \%)$ describes themselves as being Russian, Ukrainian, ruski or Orthodox, while describing their ethno-national identity.

\footnotetext{
${ }^{4}$ Ryszard Radzik writes: "[...] both peasant Belarusian language and Russian, being perceived as an urban one, are not treated in national categories. These languages are the carriers of cultural, regional and class identity, but not national one. Their status is different, but it is related to different social positions rather than national ones" (2003: 137). The hypothesis of a language significance being similar in the structure of national identity among Belarusians in Poland and Belarus could be an attractive research area in future.
} 


\section{Conclusions}

In conclusion, one has to admit there were numerous reasons why the Orthodox denomination was the slowing factor during the assimilation process towards ethnic Polishness, not constructing its religious identity on an essential national distinction from the Polish (in my opinion it would accelerate the assimilation process towards Polishness), but on the contrary, Polish values were undoubtedly accepted among Orthodox followers. It was, at least in the eastern part of the province where being Polish did not mean being Roman Catholic any more. The Orthodox Church broadened the concept of "Polish" with the possibility to be Orthodox that was conducive to forming the idea of religious pluralism in Poland. In other words, it undermined a centuries-old stereotype of Polish/Catholic being conducive to shaping a modern concept of a Polish nation being pluralistic as far as religion is concerned.

Secondly, the Orthodox denomination supported forming the regional identity, since religious life flourishing in Białystok reinforced the opinion of this town as being the genuine centre of Orthodox life both in the region and in all Poland. Orthodox religion clearly strengthened residents' regional identity making Białystok become a center of Belarusian ethnic minority in Poland, people deeply rooted in the region where they can openly express their religious and national expectations.

In the Podlaskie Voivodeship Orthodox denomination has inevitably become nationally pluralistic; this feature is more and more accepted in pastoral service. First of all, it established its structures in major state/political institutions in Poland, becoming an essential part of religious education in schools.

At present, Orthodox Church is becoming a multi-ethnic and multicultural institution, making religious, historic and cultural bases to build several specific forms of national identities in the Podlaskie Voivodeship, including Polish (it regards the Orthodox Church followers assimilated towards Polish identity), Belarusian, Ukrainian, Russian, Ruthenian or, simply, Orthodox.

In the Podlaskie Voivodeship, the Orthodox denomination fulfilled the national functions, especially during the first stage of forming the nation, in the stage when the sense of distinction from Polish majority was shaped. It could be argued it also had an important role in the second stage, the stage of national consolidation, when cultural content of newly constructed nations was formed. The Orthodox religion provided the nations with at least several basic values, social norms and group solidarity attitudes.

Another important feature concerning forming the identity of Belarusian minority that Orthodox Denomination holds is its autocephalous nature. The Orthodox Church in Poland autonomously shapes its relations with the Polish state and Polish society. Basically, the Orthodox influence on national identity formation in the borderland area inevitably undermines the identities based on civilizational bases. The Orthodox followers being at the same time the Polish, the Belarusian, the Ukrainian and, even, the Russian in Poland, move the civilizational border between the East and the West more and more towards the East. Similar processes occur in the Western Ukraine, Belarus and inside the Ruthenian world - inside the Russian Federation. 
Finally, I wish to indicate the similarities related to socio-political and cultural status considering both the Orthodox Church and Belarusian national minority in Poland. Both communities being analyzed share the minority status that brings them closer to each other, making their co-operation construct the new socio-cultural order, characteristic for civil, creative multicultural society.

\title{
References
}

Babiński, G. 2003. Etniczność i religia - formy, płaszczyzny i poziomy powiązań, w: Posern-Zieliński, A. (Red.). Etniczność a Religia. Poznań: Wydawnictwo Poznańskie, 12-17.

Babiński, G. 2004. O etniczności i religii - uwagi metodologiczne, w: Borowik, I.; Hoffmann, H. (Red.). Światopoglad: między transcendencja a codziennościq. Kraków: Zakład Wydawniczy Nomos, 263-275.

Babiński, G. 1999. Religia i tożsamość narodowa - zmieniające się relacje, w: Kempny, M.; Woroniecka, G. (Red.). Religia i kultura w globalizujacym się świecie: Materiały konferencyjne. Kraków: Zakład Wydawniczy Nomos, 197-211.

Bauman, Z. 1996. Socjologia. Poznań: Wydawnictwo Zysk i Spółka.

Bystroń, J. S. 1995. Megalomania narodowa. Warszawa: Wydawnictwo Książka i Wiedza.

Radzik, R. 2003. Kim sq Białorusini?. Toruń: Wydawnictwo Adam Marszałek.

Sadowski, A. 1991. Narody wielkie i mate: Białorusini w Polsce. Kraków: Instytut Religioznawstwa, Uniwersytet Jagielloński.

Sadowski, A. 2012. Wyznanie prawosławne a naród - ze szczególnym uwzględnieniem województwa podlaskiego, w Lewowicki, T.; Różańska, A.; Klajmon-Lech, U. (Red.). Religia i edukacja międzykulturowa. Toruń: Wydawnictwo Adam Marszałek, 159-171.

\section{KŪRYBINIS RELIGIJOS VAIDMUO PALAIKANT BALTARUSIŲ ETNINĖS MAŽUMOS NARIŲ TAUTINI TAPATUMĄ LENKIJOJE DEMOKRATIJOS SĄLYGOMIS}

\author{
Andrzej SADOWSKI
}

\begin{abstract}
Santrauka
Pagrindinis šio straipsnio tikslas - parodyti kelių hipotezių religijos ir tautos santykio atžvilgiu nepagrįstumą. Straipsnio pradžioje pristatomas religijos ir tautos tarpusavio santykis, kuris analizuojamas literatūroje, siekiant atsakyti ì klausimą, kodèl tautoms reikalinga religija. Analizuojamas Ortodoksų Bažnyčios Lenkijoje vaidmuo ir svarba. Ši Bažnyčia - tai etniškumo prieskyra baltarusių tautinei mažumai Lenkijoje, ypač Palenkès vaivadijoje kaip pagrindiniame šios bendruomenès gyvenamajame areale. Tikètina, kad artimiausioje perspektyvoje ortodoksų religija atliks reikšmingą vaidmenį kuriant daugiaetnę ir daugiatautę lenkų kūrybos visuomenę.
\end{abstract}

Reikšminiai žodžiai: baltarusių tautinè mažuma, kūrybingumas, ortodoksų tikèjimas ir jo tautinis tapatumas. 